\title{
ADRIENNE WARD
}

\section{APPROACHING TWO WOMEN: DE SICA'S FILM FROM DIFFEREN'T ANGLES}

In 1960 Vittorio De Sica adapted Alberto Moravia's 1957 novel, La ciociara, to create the film Two Women, starring Sophia Loren and Jean-Paul Belmondo. Both works relate the story of a mother and daughter forced to evacuate Rome during World War II. Taking refuge in the mountains outside the city, the two women experience a series of encounters with other evacuees and military personnel, leading to a climactic scene in which the daughter, Rosetta, is raped by Moroccan soldiers. The story ends as the war draws to a close, and Cesira, the mother, is faced with her daughter's sudden sexual promiscuity and psychological impenetrability.

The brevity of this plot summary is deliberate. It serves to suggest that the points of contact between the film and its source are quite tenuous-which in turn points to the question of cinematic adaptation of literary works. James Naremore posits that current writing on film adaptation wavers between two fundamental metaphors: adaptation understood as "translation," and adaptation understood as "performance" (Film Adaptation 7-8). ${ }^{1}$ The translation brand of criticism looks carefully at the formal systems operative in the two types of texts, written and filmic. Focusing on similarities, at least those of effect, given that means are likely diverse, the translation approach is motivated by a "separate but equal" philosophy in its treatment of the two genres. Although not viewed favorably, what Brian McFarlane terms "fidelity criticism" also falls into this category, given that the concern with faithful representation certainly assumes that a film is in someway translating its predecessor $(8-30) .{ }^{2}$ The performance variety of adaptation criticism is not nearly as interested in the literary text. Instead, it privileges the film medium, to see how the filmmaker reinvents its source, or, put another way, recreates the "aesthetic experience" of its source (Marcus, Introduction 14). Performance criticism concerns itself with differences between the two works, not similarities, with individual style and creation rather than formal generic codes. 
This study will examine De Sica's Two IF'omen in light of these two theoretical stances on film adaptation. My analysis is greatly facilitated by the fact that the most recent studies of the film exemplify the two positions. Millicent Marcus' 1993 essay "De Sica's Two II'omen: Realigning the Gaze," calls the director to task for neglecting the novel's essential attributes. Narcus claims that in not rendering the compelling ambivalence of La ciociara, De Sica betrays Moravia's fundamental ideology: that history writes itself irreversibly on the body, and humanitarian ideals should take precedence over shallow materialism. De Sica's omission is all the more lamentable since his earlier neorealist films show him fully capable of using cinema innovatively for complex, atypical ends. Marcus notes a couple of instances where De Sica offers "technical equivalents" of Moravia's narrative strategies, but these are regrettably too few and far between (85-90). In concentrating on the ways in which the film compromises the novel, or constitutes a "bad translation," Marcus deploys the translation model of adaptation theory. ${ }^{3}$ Faye McIntyre's 2000 study on the other hand, is negligibly concerned with Moravia's text. "In Love and War: Vittorio De Sica's Two " "omen" instead reads the film in light of the shared neorealist project of De Sica and screenwriter Cesare Zavattini. Noting that Two Women embraces neorealist thematics more so than style, McIntyre defines the former as the destruction of idealized, narcissistic relationships so as to make way for human alliances based on sympathetic identification. "For De Sica $[\ldots]$ it is necessary to experience [...] the destruction of one's illusory sense of connection to and identity with others" (248); "Innocence or wholeness or integrity can only be re-established when the I relinquishes its illusory authority over the idealized Other" (249). The film's authors had great faith in cinema's power not only to unmask such defective social relations, but also to expose the spectator's own complicity in problematic historical conformity. McIntyre examines Two Women solely in terms of its rendition of this ethos. To this end she juxtaposes the movie with other films from De Sica's oemure which also evince this ideology. Since she clearly highlights the filmic medium and seeks to explicate the director's unique artistic achievement, her study illuminates De Sica's "performance" of the novel.

While both Marcus' and McIntyre's treatments offer rich readings of Two I" omen, they are also limited, by cleaving too closely to their respective foundational metaphors. This study intends to point out these limitations, and in so doing provide an alternate reading of the film, to respond to Naremore's call for "a more flexible, animating discourse in film studies" (Film Adaptation 9). The very fact that the two critiques contradict one 
another-Marcus sees in Tw'o II"omen an abandonment of De Sica's neorealist iconoclasm where Mclntyre sees its indisputable elaboration-suggests that there is more at stake, and that a wider critical net might yield more fish. Let us first examine Marcus' vision of De Sica's film as a translation of its source.

While Marcus's in-depth discussion of the novel and its masterful complexity does not include mention of the classical realist narrative tradition, it should be cited to fully appreciate La ciociara. Moravia's novel is clearly an example of classical realist fiction insofar as it exhibits most of the genre's principal characteristics: temporal/linear linkage of events, cause-and-effect progression, narrative unity and closure, character-motivated action, and finally, assumption of the text's fundamental "truth," conveyed through the allegedly accurate representation of highly plausible events. ${ }^{4}$ In certain instances, howerer, Moravia takes liberties with particular conventions attached to realist narrative. Indeed, the novel's power and resonance ensue precisely from these deviations.

He deviates first with his use of first-person narrator. W'here a strict realist text privileges third-person omniscient narration to best purport the authority of its truths, Moravia's tale rests in the perceptions of Cesira, who relates the entire narrative in memoir fashion. Although Moravia constructs in Cesira a very down-to-earth character, of such common sense that the reader is drawn to trust her depiction of the facts, the very fact of subjective interpretation of those facts destabilizes credibility. In addition, as Marcus points out, Cesira's frequent references to her story-telling role remind readers all the more of the filter before them, further weakening the illusion of truth that impersonal narration generates simply by virtue of "its effacement of its own status as discourse" (Belsey 72). ${ }^{5}$ In choosing first-person narration, Moravia admitted his questioning of narrative objectivity and his intention to explore the problematic relationship between the individual and the world:

La terza persona non consente che la rappresentazione immediata, drammatica dell'oggetto; la prima persona permette di analizzarlo, di scomporlo, e, in certi casi, addirittura di farne a meno [...] la materia dei romanzi di memoria per forza di cose è ordinata secondo un tempo ideale o ideologico che non è quello naturalistico delle rappresentazioni dirette e drammatiche. Questo tempo ideale e ideologico richiede un intervento continuo della riflessione, un commento continuo della ragione ("Nove domande" 40). ${ }^{6}$

Moravia is not interested in the easy, overarching coherence offered by invisible, speakerless narration, and his desire to mediate direct represen- 
tation throws into question his faith in the abilities of the realist tradition to adequately illustrate human experience.

The latter half of Moravia's remark points to a second break with classical realist canons. As he states, the memoir novel requires a temporal structure that is "ideological rather than naturalistic," and thus manipulates the purely linear continuity of the standard realist narrative. In other words, he resists the realist tendency to situate a story in a single uninterrupted past that remains in the past, start to finish. Cesira's story contrasts the "past" time of the events narrated with the "present" time in which she remembers and relates them:

Si stava male e adesso, ripensandoci, posso dire che, in tutto quel tempo della guerra che passammo fuori di casa, mai sono stata così male come da Concetta (45).

Che tavolata! Me ne ricorderò finché campo, un po' per le stranezze del luogo, e anche un po' per l'abbondanza (69).

Quel pomeriggio io passai a pulire la stanzetta dove era il nostro letto e dove non sapevo che avremmo dovuto vivere così a lungo (78).

Lo ricordo l'elenco e io riporto qui per dare un'idea di cosa fosse la vita della gente nell'autunno del 1943 (94).

While the "present" articulated through Cesira's comments is not fleshed out substantially enough to seriously disrupt the overall flow of the recounting of past events, its recurrence does underscore the question of narration and reliability. For example, Cesira's increased knowledge through time spotlights the limits of the text's absolute "truth" at any given moment. As Marcus notes, there are two Cesiras-protagonist and narrator-whose coexistence in the novel complicate the usual hierarchy of discourses and thus calls attention to discourse itself (69). ${ }^{7}$ By multiplying the temporal locations and juggling narrative levels, Moravia clouds narrative objectivity and puts strain on the unity and closure critical to the customary realist text. More importantly, this stress open spaces for more conscious interpretative activity, increasing the reader's awareness of his or her own subjectivity.

Moravia's use of first-person narration and temporal heterogeneity is crucial to his aim. As Marcus notes, "Cesira's compulsive need to justify her digressions, to state the rationale of her narrative ordering, is [...] Moravia's way of explicitly relating each episode to the novel's overall ideological structure" (68). To be more precise, Cesira must tell the story because only she is so intensely invested in Rosetta's corporal significance, from within the multiple perspectives of loving mother and interested 
marriage broker. Cesira must further recount the story from different chronological points, because only in this way can Rosetta's physical and psychological degradation over time be most effectively registered-and Moravia's discourse about history's effects over time be communicated.

The movic on the other hand, according to Marcus, does not deviate nearly enough from its industrial and generic dictates. Focusing on Cesira's body and not Rosetta's, it panders to industry demands of the time, which required that Sophia Loren's movie star status be fully exploited. ${ }^{8}$ Marcus regrets this compliance, for with it De Sica forswore an invaluable opportunity to create a truly ground-breaking film. The narrative presents Rosetta's body through her mother's eyes, but Cesira's gaze is fascinatingly bi-gendered, that is, it shifts between female and male. The text thus suggests a striking departure from the cinematic norm in which the female is objectified by a strictly male gaze. Had De Sica "aligned the gaze" in his morie the same way Moraria did in his book, his work would have constituted a real achierement. Instead, in its fetishization of Cesira's body orer Rosetta's, it adheres to an established and predictable gaze system designed to faror male visual experience and pleasure (76-77).

Such a gaze system falls within a larger body of cinematic practices inhering in standard Hollywood realism. Not surprisingly, the tenets of cinematic realism are quite similar to those of realist fiction. David Bordwell, in The Classical Hollynood Cinema, states the general rules:

[...] the Hollywood cinema sees itself as bound by rules that set stringent limits on individual innovation; [...] telling a story is the basic formal concern, $[\ldots]$ unity is a basic attribute of film form; [...] the Hollywood film purports to be 'realistic' in both an Aristotelian sense (truth to the probable) and a naturalistic one (truth to historical fact); $[\ldots]$ the Hollywood film strives to conceal its artifice through techniques of continuity and 'invisible' storytelling; $[\ldots]$ the film should be comprehensible and unambiguous; and [...] it possesses a fundamental emotional appeal that transcends class and nation (3).?

The fundamental emotional appeal to which the realist film aspires results in simplistic, semi-sensational stories of relatively fleeting consequence. Marcus laments this type of cinematic blandness when she says of De Sica's adaptation: "What Moravia had intended as a cosmic commentary on the way in which history is written on the body becomes a private morality tale that punishes Cesira for the rery desires she arouses" (79-80).

While the final effect of De Sica's film tale remains to be discussed, his film style does instantiate for the most part the authorized aesthetic of 
Hollywood realist movie-making. Aside from some extreme long shots to establish locations, the film confines itself primarily to medium and long shots, which, together with straight-on camera angles and level framing, create the filmic equivalent of third-person objective narration. This omniscient point of view dominates the movie, except for dialogue scenes, where De Sica deploys reverse angle shots between characters. Use of close-ups is very limited and occurs at highly predictable moments: De Sica focuses on Cesira's face as Giovanni is about to kiss her, and zooms in to capture Rosetta's shocked expression at the precise moment in which she is raped. Camera speed virtually does not vary, and camera movement remains static, except for the case of a tracking shot of the two women seen through the eyes of a squadron of soldiers passing them in a jeep.

However, in several notable sequences, De Sica breaks dramatically with these editorial procedures. Using unexpected angles, distances, and frame composition, he disrupts the even flow of continuity editing and thereby shifts his cinematic text outside the realm of pure storytelling. In doing so he reveals his awareness of the power of cinematic artifice to expose gray areas and engage the spectator more consciously.

The first scene to show a markedly atypical formal approach involves the meeting between the triad Cesira, Rosetta and Michele, who are taking their daily walk on the macera, and the two Italian fascists who arrive to announce Mussolini's imprisonment. Initially, this sequence does not depart from the cinematic patterns offered up to this point in the movie. De Sica employs medium to medium-long shots to portray the encounter, and shot/reverse shot editing accompanies their dialogue. Then, suddenly, point of view shifts as the figures are shot from ground level. The camera is far enough away to capture the full length of the four figures (four rather than five because Cesira embraces Rosetta so tightly that they appear as one). They appear nearly equal in height and equally spaced from each other: Cesira/Rosetta and Michele stand directly opposed to the two Black Shirts. From the extremely low position, no part of the background landscape is visible save for the dim profile of mountains. The looming masses of their bodies, positioned evenly like statues, or columns, stand sharply against the white space of the sky.

The scrupulous composition of this scene cannot be ignored, as De Sica deviates from the straight-on, level shooting patterns that have dominated the film thus far. More significantly, he abandons the movie's two privileged points of view-that of character and of objective immediate onlooker. Instead, he confronts viewers with an entirely unassignable optic. It cannot belong to the impersonal witness given the point of view 
thus far established for that spectator. That this gaze is highly subjective appears evident, but who is this subject? Nothing to this point has prepared viewers for the blatant stylization of this scene.

In terms of diegesis, the gigantic stature of the characters in this scene articulates the enormity and intensity of their conflict. The personal and immediate antagonism between Cesira/Michele and the two beleaguered fascists inflates to occupy the larger proportions of the clash between political factions-fascists v's. partisans, fascists v's. allied troops, fascists vs. objectors to war. Ultimately, however, the monumentality of the opposed figures reflects the epic dimensions of the great divide between agents and victims of war. The subject position located at the characters' feet serves to communicate the dwarfed status, the reduced power, the inconsequentiality of third parties to the struggle. ${ }^{10}$

One can also identify in this mise-en-scène the influence of film noir techniques. While Two IVomen does not qualify as a bona fide noir film, the oblique shooting angle and expressive lighting (cfr. the stark outline of the dark bodies against the brightly-lit background) effect a compositional tension regularly associated with noir cinema and its thematic fatalism. ${ }^{11}$ Thus in both its oppressive mood and the disorientation produced by its idiosyncratic camera position, this scene fractures the realist trance and induces in the spectator a more heightened awareness of his relation to historical events.

A second exception to the film's realist canons occurs during the rape scene. Like the macera sequence noted abore, this scene begins with the familiar medium and long shots, which initially function to establish Cesira's and Rosetta's presence in the church. Likewise, the first shots of the soldiers' chase of the women follow prescribed eye-level strategies, following now the soldiers, now the women, at times fitting both assailants and victims in a single frame. It is thus surprising when De Sica cuts away to a bird's-eye shot of the attack, as seen from the lofty rafters of the church. De Sica will repeatedly interrupt the normative shots of this sequence with this overhead view.

Compared to the eve-level shots, the ceiling optic embraces much more of the desecrated interior space of the church, wound through with the swarm of soldiers running in great circles after their prey: The overhead scenes impart a sense of totality-not just the parts, but the whole of the event is offered. This viewpoint (again anomalous within the range of optics to this point) infers a superior, transcendent position, from which the incident below becomes a single episode in a continumm of events. Might the omniscience eroked by this point-of-riew relate to a 
notion of divine knowledge or universal justice, such as that which Moravia's Cesira conjures in one of her final descriptions of Michele: "[...] lui ci aveva una forza che a me mancava, perché lui era non soltanto buono ma anche istruito e sapeva tante cose e giudicava sui fatti della vita dall'alto e non terra terra come me" (emphasis mine) (292-93)? Or does the bird's-eye shot jar spectators from their immersion in the story so as to provoke reflection on the story's significance in a vaster universal narrative? In either case De Sica deliberately provides a perspective which distinctly echoes aspects of Moravia's historical discourse as identified by Marcus: that the private is subordinate to the public, that the personal cannot stand as a "bulwark against history" (73).

At this point it is revealing to note the film's addition of a bomb hole blown through the church roof. This detail is absent from the novel, but in the movie obviously serves to reinforce the parallel between rape and war as inhuman invasions. The roof laceration appears on-screen only from the point-of-view of the women: Rosetta looks up to it just before the assault ensues, and it is the first thing Cesira sees as she comes to following the rape. But this site serves a more instrumental function than that of simply adumbrating and confirming their attack. The bird's-eye view discussed above, the privileged position which ostensibly "sees all," might easily be aligned with the locus of the opening. That is to say, the bomb hole potentially permits the overhead view. The overhead optic now assumes a high degree of ambivalence. It is transgressive because it originates in destruction, and proposes a subject position which itself invades and penetrates. It implies the capacity to be where one should not be, to witness what one should not witness. On the other hand, the roof-hole view is salvific. It enables the detached contemplation cited earlier, with its divine re-visioning of human travails. The perforation lets in the "holy" light that shines on Rosetta, stressing the redemptive power of her sacrifice. The only literal correlative to the film's punctured roof in the novel is the hole that Cesira rips in the thatch of the abandoned mountain shack to free a group of trapped goats. As she herself muses, it seemed that the liberated goats "mi ringraziavano di averle salvate dalla morte per fame" (266). Considering for a moment De Sica's belief (as McIntyre presents it) in the destruction of idealized, self-seeking relationships as the only route to meaningful human connection, it could even be surmised that the subject insinuated in the roof laceration site must himself destroy to properly "see" - that is, to enter into compassionate relationship with others. W'reckage is twofold then: it lays waste to human dignity while also toppling the barriers to redemption; it is not necessarily visited upon a passive 
subject-victim, but might be an act executed by an active subject-perpetrator. With the overhead shot De Sica blurs the neat lines of realist convention and again implies the subject's ambiguous complicity in contingent events.

A third scene wherein the precepts of Hollywood realism are temporarily discarded portrays Cesira and Rosetta riding with Florindo, in the cab of his truck. Rosetta is seated between the two adults and reverse angle shots are deployed to film Florindo and Cesira as they speak. In the midst of this predictable shooting however, point-of-view shifts from that of the characters to a straight-on shot from bebind passengers and driver. Their heads and shoulders are seen from the back, as well as the interior windshield section of the truck cab, with various postcards affixed to the visors. Directly above Rosetta hangs a "girlie" postcard, adjacent to what appears to be photos of a military tank and of an officer (perhaps Mussolini?). A portrait photograph of a woman is clipped to the visor above Florindo's head.

Like those identified above, this optic cannot be ascribed to any of the film's inhabitants nor to the objective onlooker. The characters never reference the visor paraphernalia, and the scene is unnecessary as an establishing shot, since it is clear where the characters are. ${ }^{12}$ Once more, De Sica interrupts the realist editing pattern with an alien point-of-view that thrusts the spectator into a more deliberate interpretive role.

Rosetta's central position between Florindo and Cesira suggests that their existences are in some way oriented around her. Recalling previous triad compositions helps to determine the nature of this orientation. In a scene on the macera, while Cesira and Michele chat in the foreground, Rosetta, who has wandered off from them, sits discreetly in the distance, positioned equally between the twro adults as if at the top of a triangle of which they form the other points. Cesira and Michele discuss his religious leanings and her business savvy. Their combined cynicism unites them, in opposition to the remote Rosetta, embodiment of a transcendent spiritual purity: At the same time Rosetta links the two characters, insofar as through her Cesira will come to a greater understanding of Michele's message. Likewise, the episode in which Michele argues so rehemently with the German commander over lunch positions Michele's lawyer friend and fascist sympathizer as standing directly between the two seated men, center-screen. In this case also, the lawyer is at once separate from their conflict (he is its frightened victim) and its mediator. His over-earnest efforts to please the German with an abundance of food and his opera singing give the lie to his displeasure over the war and its forced performances, an attitude which lies more in line with Michele's. 
The juxtaposition of the postcard and photographs directly over Rosetta provokes a less subtle reading. The sexual and militaristic images mark Rosetta as the crucial point of convergence for various manifestations of physical and psychological transgression, both public and private. ${ }^{13}$ Perhaps because he was constrained to highlight Loren's star status for so much of the film, De Sica resorted to this symbolic albeit overdetermined montage to refocus attention on the daughter figure and the confluence of meanings in her character. In any case, the scene clearly thwarts Hollywood realist efforts to conceal filmmaking artifice and forces an active intellectual appraisal of the scene.

Let us now turn to McIntyre's treatment of Two Women, which illustrates the "performance" mode of film criticism in its general disregard for its fictional source and its emphasis on cinematic concerns. Except for two brief citations of shared aims between novel and film: "in the novel, as in the film, Cesira's home is both a self-reflecting sanctuary and a sign of her status and identity"; "both the novel and the film suggest the need to interrogate the notion of innocence and its too-frequent association with respectability" (251), McIntyre excludes the narrative and Moravia. ${ }^{14}$ Instead, she stresses the filmic achievement by organizing her argument around the stated neo-realist ethos of the movie's creators, citing as well its incidence in Garden of the Finqi-Contini, Bicycle Thieves, and Indiscretion of an American W'ife. In all of these films De Sica portrayed the crisis of disillusionment, that is, the shattering of the idealized, ego-centric relationship to the world, which in turn allows for a more balanced, empathic vision of self and others. According to McIntyre, De Sica rendered this crisis through character action and dialogue, the spatial compositions of certain scenes, and unusual filming trajectories and unexpected or jarring points of view. Unfortunately, however, despite a penetrating analysis that illuminates the movie as eloquently as Marcus's, McIntyre devotes excessive attention to the story line, overlooking telling cinematic patterns that if identified would bolster and clarify her thesis.

McIntyre opens her discussion commenting on the use of still photographs as background to the movie's opening credits. She notes the serenity in the content of the pictures, one dissolving into another. She then remarks on how the intrusion of sound and movement (the wail of an air raid siren erupts over the final picture, at which point the still comes to life and the film's action and soundtrack begin) evince the (film) camera's presence, as an observing outside authority that "opens up," even "terrorizes" the images. In McIntyre's view, the still pictures represent the safe, untouchable vault of history, whereas the insertion of sound and 
activity suggests a disruptive, unpredictable present (242-243). In terms of the ideology espoused by the film's authors, this discordant present serves to provide the crisis that challenges narcissistic vision. McIntyre's insightful observations on the role of photographs, and on the dialogic possibilities between visual stillness and visual motion, as well as that between silence and sound, can be extended to other sections of the film.

As previously mentioned, De Sica also featured photographs in the truck cab scene, where snapshots of a pin-up girl, a military tank and war commander hang above Rosetta's head as riewed from behind. Unlike the static pictures at the film's open, each of which occupied the screen until the final still was displaced by its transformation into a moving picture, the photos affixed to the truck's visor coexist within the moving picture. Following McIntyre's generic association of photographs with the past, and filmed action with the present, in this sequence the past insinuates itself into the present and clings tenaciously to the lived moment. ${ }^{15}$ To complicate matters, however, where McIntyre identifies the opening photographs with the security of an inert, pre-war past, subsequently dislodged by a frenetic, unruly war-time present, the truck cab tablean confuses the terms. Here the cheesecake postcard and military snapshots clearly embody a threatening, immoral and dangerous present. The violent devastation brought about by sexual license and military aggression are prevailing elements of Cesira and Rosetta's current world. The filmed sequence of their ride in Florindo's truck, however, also comprises the present. This present focuses on purity and intactness, personified in Rosetta. By her contrast with the visor pictures and their connotations of immorality and destruction, Rosetta is figured not only as unblemished, but also as fragile and endangered. This image constitutes Cesira's operative vision of her daughter. Cesira's obsessive pride in Rosetta before the rape, and her intense suffering afterward, result because of her continual conceptualization of Rosetta as an innocent but imperiled being. One version of the present, therefore, as embodied in the photographic representations of the ravages of war, battles with another version, embodied in Cesira's notion of her daughter's precarious status. The tension Miclntyre located at the film's beginning between completed events (the past) and events in process (the present), has advanced and intensified. It now agitates wholly from within the present moment. Manipulating his iconographic vocabulary of still and moving images, De Sica thus conveys the devastative power and immediacy of the crisis of narcissistic perception.

The movie's soundtrack also offers a way to read the film's rendition of the crisis necessary to wholeness. While Tu' W'omen respects Hollywood 
realist practice in its soundtrack design, that is, it uses parallel synchronous sound and speech that refer wholly to the material properties of their sources, the patterns of those literal sounds, when analyzed, reflect the tension and brutality of the self's break with limiting modes of relationship. ${ }^{16}$ The contrastive relationship between silence and sound that McIntyre cited at the film's start, where silence signals safety and sound danger, is reprised in several places in the film. The sound of bombs dropping breaks the silence of the two women's walk along the country road toward Fondi. The sound of approaching army trucks or tanks speeding along the road also ruptures soundless episodes between Cesira and Rosetta, alluding to the impending danger and violence associated with military machinery. This grammar of noise-silence appears to reverse itself when Rosetta is raped, and her scream-embodying resistance and outrage over the war crime-fades to silence. But like the truck cab scene, which communicated the accretion of anxiety by eliminating the palliative "past" and concentrating tension in the present moment, Rosetta's silence does not, like the earlier silences, counter the noise of wartime terror. Rather it belongs entirely to it. In other words, now sound and silence are both contaminated; there is no longer an antithetical term.

In other sequences, two sounds compete for dominance, where one represents wartime violence or tragedy and the other marks efforts to reduce or evade them. Michele's impassioned speech decrying the war vies with the accordion playing of the anniversary celebrants. Continuous interruptions - children begging for bread, Cesira crying over an upsetting letter about her losses in Rome, villagers discussing where they might procure food-assail Michele's soft-spoken reading of a biblical passage. The loud argument between Nichele and the German army official at the Italian lawyer's home threatens to overpower the whispering of the women, Cesira and her frail hostess, in the kitchen. They are finally drowned out by the opera singing the German officer imperiously demands of his host. Overwhelming sound or sound itself constitutes an invasive force that constrains those subject to it to alter their course: airraid sirens and falling bombs cause people to run for cover, verbal interruptions provoke Michele to cease reading, the roar of approaching military vehicles stop pedestrians in their tracks. Sound denotes the crisis point-it divides the before from the after in the process of destruction that putatively leads to greater self integrity.17

A good portion of McIntyre's critique directs attention to the effica$\mathrm{cy}$ of the parent-child relationship in facilitating the crisis-maturation process. In this paradigm, crisis ensues in a severed bond between parent 
and child, whereby both share the experience of loss. Their rift however, occasions their reunion and their redemption, and here the parent's salvation is especially significant (and more hard-earned), since it has been the parent's selfish act of making his/her child the repository for some secret, vulnerable part of himself/herself that has distorted their relationship in the first place. Redemption is possible provided the parent recognizes in the child's gesture of good faith following the trauma-Bruno's reclamation of his father's hat from the crowd of detractors, for example - a sign of hope and reparation (McIntyre 249-57). In the case of Tn'o I"'omen, Cesira must be able "to see in her child's renewable feelings of grief the hope of her own escape from the isolating stupor of a life lived only for material gratification" (250).

But McIntyre seems uncertain as to whether Cesira actually recognizes such an option. On the one hand, she observes "Rosetta's reaching out to her mother in the final moments of the film, after hearing of Nichele's death, is an indication to Cesira that Rosetta, and she herself by implication, might be absolved from complicity in their imposed destiny [i.e., objectification]" (250). On the other hand, McIntyre remarks that the finat scene "seems to leave parent and child in their shared isolation $[. .$.$] the$ camera allows mother and daughter to be 'merely' photographic subjects" who, as the camera pulls stowly back, are eventually overshadowed by a foreground image of a peasant's cart (257). It is not clear if Cesira's reintegration has been successful, if she has forged a new integrity.

A more attentive study of the film's ending, including an examination of the novel's conclusion, will help to answer this question. Not only will we see that what McIntyre indirectly suggests is true, that is, that De Sica offers an extremely ambiguous portrayal of the reparation phase, but we will also see with greater precision how such skepticism is expressed. Exploration of De Sica's filmic decisions at the end of Tn'o IV'omen will furthermore show how-or possibly if - he recreates the aesthetic experience of his source.

In the novel, Rosetta's transformation following the rape traumatizes Cesira, who reets between registering the enormous changes in her daughter and sensing the unchanging flow of life and time that continues despite such trauma. With regard to the first state, Cesira herself narrates her dismay in front of Rosetta's new habits, which include her apathetic silence, even as she hears of Michele's death, her disregard for her mother's prohibitions, and her sexually promiscuous dress and actions. But Moravia utilizes an additional narrative strategy to communicate Cesira's severe disorientation. Thus far her narration has progressed with regular allusions to 
her incorrect perceptions ("if I'd only known," "little did we suspect..."). Now, as the novel ends and the gap closes between protagonist (past) and narrator (present) of the story, Cesira's allusions to her mistaken thoughts cease. At this point she relates her tale fully from the past, wrapping up the events of that tragic period. And ironically, at this final moment, she makes a concentrated series of misperceptions as psychologically traumatic as any that has come before. As the two women are returning to Rome, Cesira resigns herself to Rosetta's relationship with Clorindo, and starts to envision the possibility of their happy and prosperous marriage. This reverie, however, proves the first of a chain of mistaken conclusions Cesira will make, when Rosetta flippantly informs her Clorindo is married and has children. Nothing is what she thought it was, as Cesira finds out in rapid succession that Rosetta is not upset by this fact, that Clorindo has already left her to return to his family, that Rosetta learned the truth about him only the night before and does after all have feelings about it, that Rosetta has been sexual not only with Clorindo but with several of his friends (286-291). IVith unrelenting momentum Cesira's beliefs reveal themselves to be mere illusions, popping like bubbles one after the other.

Cesira's second state, her awareness of the unceasing stream of life, indifferent to horrific tragedy, is also rendered through her commentary:

Prendemmo la strada maestra, soleggiata, pulita, chiara, nel vento di primavera che soffiava dolce alle orecchie e pareva dirmi che non dovevo prendermela, tanto tutto continuava come prima, come sempre (263),

as well as by the persistence and monotony of Concetta's empty chattering. The simplistic logic and repetitive sing-song rhythm of Concetta's remarks furnish a textual equivalent of disinterested time and impervious history marching onward:

"Eh, si sa, la guerra è la guerra" (277)

"I a gioventù è la gioventù" (280)

“...finché c'è la salute, c’è tutto" (276)

"Piangi, piangi, che ti fa bene" (278)

"Sono cose di una volta; con la guerra, si sa, tutto è cambiato, i giovani fanno la corte alle ragazze senza dire loro che sono sposati, e le ragazze fanno l'amore con i giovanotti senza chiedere loro di sposarle. Cose di una volta, tutto è cambiato..." (289)

"...noialtre madri dobbiamo capire e perdonare, perdonare e capire." (292)

Cesira resents Concetta for many reasons, only one of which are these grating platitudes, but she also must begrudgingly admit their truth, in the 
same way that she must accept history's inexorable and indiscriminate progress.

Notwithstanding these elaborations of Cesira's plight, Moraria's narrative ends conclusively with her salvation. Her deliverance comes about in two stages. She first has a dream, in which Michele stops her from committing suicide (294). Cesira calls this erent a "half-miracle," because although she chooses to live, she does not yet understand why life is worth living. Her redemption is completed when Rosetta begins to sing again. As Rosetta sings she cries, and Cesira sees in this dual expression of feeling a definitive sign of the value of life. Her faith and trust in living is renewed by this simple restoration of a former part of Rosetta.

On her first glimpses of St. Peter's dome as they re-enter Rome Cesira reflects:

Laggiù, in fondo all'orizzonte, quella cupola mi diceva che io potero ormai tornare fiduciosa a casa e la vecchia rita avrebbe ripreso il suo corso, pur dopo tanti cambiamenti e tante tragedie. [ ...] questa fiducia tutta nuova, io la dorevo a Rosetta e al suo canto e alle sue lacrime [...] il dolore ci areva salvate all'ultimo momento (307).

Two II"omen, in contrast, terminates much less categorically: Returning again to the truck cab scene, De Sica films the conversation between Florindo and Cesira using the expected reverse shot pattern. The mute Rosetta sits between the two and appears in the foreground of the shots of Cesira, where Florindo's speaking shots feature his face alone in the screen. Visually, De Sica aligns Rosetta with her mother, countering Florindo. As their conversation progresses, however, and Florindo attempts to engage Rosetta, De Sica switches the shot composition, putting Rosetta into the frame with Florindo during his speaking turns. The optically-paired Rosetta and Florindo now oppose Cesira. In altering Rosetta's screen placement, De Sica graphically depicts her journey from the protective, imaginary universe her mother envisions for her, to the real, concrete, and predatory world to which Florindo belongs. Even as Rosetta returns to share the frame with Cesira at the end of this sequence, she has been depicted visually as an entity in contention, susceptible to two rersions of reality. The episode's final moments decide it-Rosetta affiliates herself with Florindo, as she accepts his invitation to sing. To remind viewers that Rosetta's passage actually marks her mother's flawed hold on reality; the last scene features a close-up of Cesira's anguished, tear-filled face, with her daughter's feeble roice singing in the background.

The series of scenes that follow Cesira's awakening in the middle of the night to find Rosetta missing also underscore her vulnerability and 
estrangement. These frames repeatedly position a solitary Cesira in the midst of a large, menacing landscape. After running outside to look for Rosetta, she is shown in various shots standing alone gazing out at the countryside, hugging herself beneath a row of tall trees, desperately calling out to neighbors in the center of the yard, surrounded by the high walls of their houses. One of the last scenes before Rosetta's return shows her seated alone on a ledge, waiting at the end of a road which stretches away from the precise screen center. As a truck approaches Cesira rises to meet it, guessing that it might contain Rosetta. The jeep holds only soldiers, however, and swerves away from her as it passes, leaving her alone once more.

The image of the passing military jeep deserves closer attention. Like the recurring figure of the pietà, that of traveling wartime vehicles constitutes another of what Marcus calls a "governing image" in the film (78). It represents one of the most dramatic modes in which De Sica conveys the ubiquity of danger and the impossibility of total refuge. The shot of passing army trucks that likely claims the greatest attention is that of the convoy of Moroccan allied soldiers that speeds by Cesira and Rosetta as they rest along the roadside. As they pass, the men laugh and hoot wildly at the women. We see the advance of the trucks from the women's point of view, then the women are framed through the men's eyes as they spin around the curve. De Sica's use of a jerky, dizzying tracking shot here not only ruptures the relative tranquillity of the shooting patterns thus far, but also foretells the crazy abandon to which the women will soon become subject (reproduced even in the swirling, circular patterns of the chase in the church). As the trucks roar away and the women wonder about the strange-looking soldiers, the scene discharges its foreshadowing function.

This is not the first time military vehicles have been deployed to portend the rape, however. At the end of the scene in which the American tanks come upon the evacuees in the road and erupt in battle with German air fighters, Rosetta is nearly struck by a tank that has resumed its advance. And once the rape has taken place, the incidence of army conveyances increases. They now clearly emblematize ambivalence and peril, given that the Moroccan soldiers in their speeding trucks had been assumed by the women to belong to the liberation army, and thus to be friendly. As the women continue their foot journey, they again hear the howling laughter of the Moroccans in the distance. This sound overlaps with that of an arriving jeep, allowing for an instant of terror. Luckily for the women the jeep holds French officers who mean no harm to them. Still, when these military men interpret the ranting Cesira to be crazy, they do not assure 
mother and daughter any protection. Essentially, after the utter destruction of a stable sign system in the rape by alleged allies, everyone is suspect. The sound and image of the approaching vehicle comes to symbolize this constant tension.

As Cesira helps Rosetta wash herself in the stream she hears a passing motor up on the road and immediately thinks of their unguarded luggage left there. Once at Florindo's, the headlights from the jeep that approaches Cesira (and spectators) face-on as she waits for Rosetta in the pre-dawn light loom menacingly before they turn away. In a last attempt to resist the force of Rosetta's defiance, Cesira runs out into the yard to upbraid Florindo. She comes face-to-face with his empty parked truck-whereupon she slows, stops, and turns back to the house. The vision of the vehicle seals her defeat.

The sense of isolation that McIntyre identifies in the movic's final scene most assuredly does not reflect a re-vitalized connection between mother and daughter. They reassume the pietà configuration for the third time in the film, suggesting not a Christological resurrection, but rather that suffering and tragedy will constitute a regular element in their lives. ${ }^{18}$ To underscore this reality, De Sica returns to the soundtrack, capitalizing on his semiotics of the approaching truck. As Cesira quietly holds the limp, weeping Rosetta, the rumble of a vehicle going by the window breaks their stillness twice, the second time louder than the first. De Sica no longer has to represent a vehicle visually to summon the dangerous ambivalence to which the women are vulnerable. The offscreen diegetic sound of the motor functions as a form of auditory flashback, eroking a body of troublesome past images (the leering Moroccans driving by, the rape, Florindo). As these images overlap the on-screen visual of the becalmed mother and daughter, De Sica infuses their apparent serenity with apprehension. The sound further calls attention to the boundaries between private and public, story space and spectator space. ${ }^{19}$ Distinctions are blurred, as viewers confront not only the aggrieved personal relationship between mother and daughter, but also the incidence of the larger war universe on their relationship, and quite possibly, on themselves. Cesira closes the window, once more trying to shut her daughter and herself off from the light and the sound of a brutal world. Instead of emerging into the light, having integrated an imperfect reality so as to regard herself and others more compassionately, Cesira retracts - as does the camera-into a private space marked by woundedness and chronic threat.

De Sica's successful recreation of the aesthetic experience of Moravia's novel depends on how that experience is defined. Clearly Two 
W'omen does not replicate the optimistic closure emphasized at the end of Moravia's text. It does, however, express the profound and tragic disorientation attendant upon the realization that private lives are not exempt from the impositions of history or the need to connect sympathetically with others. In this respect the film repudiates its stated poetics, as McIntyre presents them. Cesira does not achieve the wholeness assumed to be the eventual outcome of one's awareness of human mutuality. On the other hand, her unsuccessful re-integration in the film reinforces the notion of the ambivalence of the human condition and the unreliability of subjective perception-the strengths of Moravia's novel according to Marcus. A careful examination of the aesthetic choices intrinsic to the filmic performance reveals significant instances in which De Sica expressed dissent toward Hollywood realist canons and concurrently evoked the text's potent ambivalence.

University of I'irginia

\section{NOTES}

${ }^{1}$ In addition to Naremore, see the following recent studies on film adaptation: Cartmell and Whelehan, Giddings and Sheen, Griffith and McFarlane.

${ }^{2}$ Tibbets and Welsh provide an excellent example of fidelity criticism.

${ }^{3}$ Ruth Prigozy also offers a translation-mode critique of the film, when she states "What is in the novel primarily an exploration, with existential overtones, of the meaning of human actions becomes in the hands of De Sica and his screenwriter Cesare Zavattini [...] a tender portrait of the misery of a mother and daughter." 78-79.

${ }^{4}$ For a more detailed discussion of classic narrative realism, see Belsey 67-84, $112-17$.

${ }^{5}$ See Sharon Wood's detailed study of Moravia's first-person narrative technique in La ciociara.

${ }^{6}$ See also Moravia "Il romanzo-saggio: perché la prima persona."

${ }^{7}$ See Belsey on "hierarchy of discourses," 70-84.

${ }^{8}$ Loren's casting was insisted upon by the movie's financial backer, Carlo Ponti, who was also the star's husband at the time.

${ }^{9}$ See Stam, Burgoyne and Flitterman-Lewis for a list of the precise filming techniques employed to create the classic Hollywood realist film, 188-89.

1"See Bondanella on De Sica's similar use of low-angle shots in Sciuscià 54.

${ }^{11}$ On the photographic and thematic conventions of film noir see Schrader, Vernet, and Naremore's More Than Night. 
$12 \Lambda$ conventional establishing shot would most likely have shown the figures frontally:

${ }^{13}$ 'nless one has read the novel to know that $\mathrm{F}$ /Clorindo is married and has a family, the picture of a woman over his head in the cab scene would have very little significance, except to convey that he is involved with a woman. The film never references his married status, and communicates his womanizing ways solely by virtue of his arrogant, cavalier personality and behavior.

${ }^{14}$ Despite several quotes from The Existentialism of A Aberto Moraria by Joan Ross and Donald Freed, Moravia is essentially absent from Mclntyre's argument because she never contextualizes these citations nor explicates their connection to her discussion of the film. See pps. 245, 246, 249, 254.

15 Visconti also makes use of photographs, often family portraits, to symbolize a (past) stable, sacred, "interiorized ideal," which is inevitably altered if not destroyed by the (present) events-wartime tragedy, political or economic injustice-depicted in his films. See for example P. Adams Sitney's discussion of the family portraits in La terra trema.

${ }^{16} \mathrm{On}$ auditory realism and Hollywood realist film sound practice, see Belton, W'urtzler, and Kenny.

17 Taleria Finucci also speaks of the predominance of the notion of "before" and "after" in the novel, where war is the watershed.

18 Marcia Landy also senses the lack of resolution at the film's end. She focuses however on the iconic significance of the pieta figure, claiming that the last scene "opens up the possibility of rethinking cherished icons of femininity and maternity;" 292.

${ }^{19} \mathrm{On}$ the varied and expressive uses of offscreen diegetic sound, see Bordwell and Thompson; Kracauer 130-131 and Cook 281-284.

\section{WORKS CITED}

Altman, Rick, ed. Sonnd Theory Sound Practice. New York: Routledge, 1992.

Belsey, Catherine. Critical Practice. London: Methuen, 1980.

Belton, John. "1950s Magnetic Sound: the Frozen Revolution." Altman 154-167.

Bondanella, Peter. Italian Cinema. New York: Lngar, 1983.

Bordwell, David, and Kristin Thompson. "Sound in the Cinema." Film Art: An Introduction. New York: McGraw-Hill, 1993. 292-332.

Bordwell, David, Janet Staiger and Kristin Thompson. The Classical Hollynood Cinema. New York: Columbia UP, 1985.

Cartmell, Deborah, and Imelda Whelehan, eds. Adaptations. I ondon: Routledge, 1999. Cook, David. A History of Narrative Film. New lork: IV. IW. Norton, 1990.

Finucci, Valeria. "Dislocation and Dehumanization in the War Novel: Moravia's La Ciociara." Canadian Journal of Italian Studies 10:34 (1987): 43-58.

Giddings, Robert and Erica Sheen, eds. The Classic Norel: From Page to Screen. Manchester: Manchester L'niversity Press, 2000. 
Griffith, James. Adaptations as Imitations. Newark: University of Delaware Press, 1997.

Kenny, Tom. Introduction. Sound for Picture. Eds. Jeff Forlenza and Terri Stone.

Winona, Minn: Mixbooks, 1993. v-vi.

Kracauer, Siegfried. Theory of Film. Princeton: Princeton University Press, 1997. Landy, Marcia. Italian Film. Cambridge: Cambridge University Press, 2000.

Marcus, Millicent. Introduction. Filmmaking by the Book: Italian Cinema and Literary Adaptation. Baltimore: Johns Hopkins University Press, 1993. 1-24.

_ . "De Sica's Two Women: Realigning the Gaze." Filmmaking by the Book: Italian Cinema and Literary Adaptation. Baltimore: Johns Hopkins University Press, 1993. 67-90.

McFarlane, Brian. Novel to Film: An Introduction to the Theory of Adaptation. Oxford: Clarendon Press, 1996.

McIntyre, Faye. "In Love and War: Vittorio De Sica's Two IV"omen." V ittorio De Sica: Contemporary Perspectives. Eds. Howard Curle and Stephen Snyder. Toronto: University of Toronto Press, 2000. 242-257.

Moravia, Alberto. La ciociara. 1957. Milan: Bompiani, 1991.

1959).

"Nove domande sul romanzo." Nuovi argomenti 38-9 (May-August

. "Il romanzo-saggio: perché la prima persona." Il punto su: Moravia. Ed. Cristina Benussi. Bari: Laterza, 1987. 105-106.

Naremore, James. More than Niglbt: Film Noir in its Contexts. Berkeley: University of California Press, 1998.

, ed. Film Adaptation. New Brunswick: Rutgers University Press, 2000.

Prigozy; Ruth. "A Modern Pietà: De Sica's Two W'omen." Modern European Filmmakers and the Art of Adaptation. Eds. Andrew Horton and Joan Magretta. New York: Ungar, 1981. 78-88.

Schrader, Paul. "Notes on Film Noir." Film Comment 8:1 (1972): 8-13.

Sitney, P. Adams. "Visconti: The National Language, Dialect, and the Southern Question." I'ital Crises in Italian Cimema. Austin: University of Texas Press, 1995. 58-78.

Stam, Robert, Robert Burgoyne and Sandy Flitterman-Lewis. New' I' ocabularies in Semiotics. London: Routledge, 1992.

Tibbets, John C. and James M. Welsh. Introduction. The Enyclopedia of Novels Into Film. Eds. Tibbets and Welsh. New York: Facts on File, 1998. xiii-xx.

Vernet, Marc. "Film Noir on the Edge of Doom." Shades of Noir: Ed. Joan Copjec. London: Verso, 1993. 1-31.

Wood, Sharon. "The Value of Illusion: La ciociara and the Female Narrator." W"oman as Object: Language and Gender in the W"ork of Alberto Moravia. London: Pluto Press, 1990. 63-78.

W'urtzler, Steve. "'She Sang Live, But the Microphone W'as Turned Off:' The Iive, the Recorded and the Subject of Representation." Altman 96-103. 